\title{
Governing refugee space: the quasi-carceral regime of Amsterdam's Lloyd Hotel, a German-Jewish refugee camp in the prelude to World War II
}

\author{
M. Felder, C. Minca, and C. E. Ong \\ Cultural Geography Group, Wageningen University, Wageningen, the Netherlands \\ Correspondence to: M. Felder (felder@bmg.eur.nl)
}

Received: 31 March 2014 - Revised: 19 August 2014 - Accepted: 20 August 2014 - Published: 22 December 2014

\begin{abstract}
Through analysing the correspondence between key refugee camp commanders based at Amsterdam's Lloyd Hotel and different authorities involved in Dutch refugee matters, this paper examines how "the Dutch state" responded to German-Jewish refugees fleeing Nazi Germany in the prelude to World War II. Using a largely Foucauldian approach to discipline, power, security and governmentality to examine the bio-, macroand micro-politics behind the management of these refugees and their lived spaces, we seek to illustrate how the Lloyd Hotel formed part of a quasi-carceral spatial regime implemented to segregate and contain those with an unclear legal status at a time of political confusion. The article also seeks to show how the involvement of different authorities at different scales brought serious implications for the status, spatial regimentation, mobilities and future of the refugees.
\end{abstract}

\section{Introduction}

This article is about the "quasi-carceral" spatial regime of Jewish refugee camps in the Netherlands during the prelude to WWII, and in particular the refugee camp created out of the Lloyd Hotel in Amsterdam. The Lloyd Hotel (see Fig. 1) was built as a transit hotel in 1921 by the steamliner company Royal Dutch Lloyd (Koninklijke Hollandsche Lloyd), to be incorporated in a network of railways and sailing routes between Europe and South America transporting Eastern European emigrants (see Ong et al., 2014a). These included, amongst others, farmers and Jews fleeing poverty, disease, famine and pogroms in the territories of Eastern Europe and Russia. Situated along the Amsterdam waterfront, the Lloyd Hotel was aimed at keeping the migrants under the control of the shipping company and at managing individuals representing potential "threats" during the crossing of the Atlantic (e.g. carriers of contagious diseases with potentially disastrous effects on the steamliner population). As such, the hotel was designed to house large numbers of people and to function as a quarantining and sorting machine (ibidem). The Royal Dutch Lloyd's passenger transportation ceased in 1934 and went bankrupt in 1938 .
However, after the dramatic events known as the "Kristallnacht" in Hitler's Germany, on 9 November 1938, a wave of Jewish refugees entered the Netherlands, escaping intensified persecution with the implementation of the infamous Nuremberg legislation (e.g. Sherman, 1973). Despite these persecutions being broadly known, most Western countries had stopped accepting Jewish emigrants at that time. Consequently, many of those who fled Germany, even if originally intended to continue their travels to other final destinations, found themselves stuck in the Netherlands, presenting the Dutch government with the acute and urgent problem of identifying and managing these refugees at a time of increasing political tensions in the prelude to WWII. As an emergency measure, the Lloyd Hotel was chosen by the Dutch Ministry of Internal Affairs, together with 25 other facilities (see Fig. 2), to temporarily accommodate these refugees before more definite arrangements were put in place (Lubbers, 2004).

In this article, we argue that the Lloyd Hotel was used by the Dutch government as a site to segregate and contain individuals with an unclear legal status at a time of political confusion, an attempt to govern the "refugee problem" by spatialising it into a network of institutions characterised by 


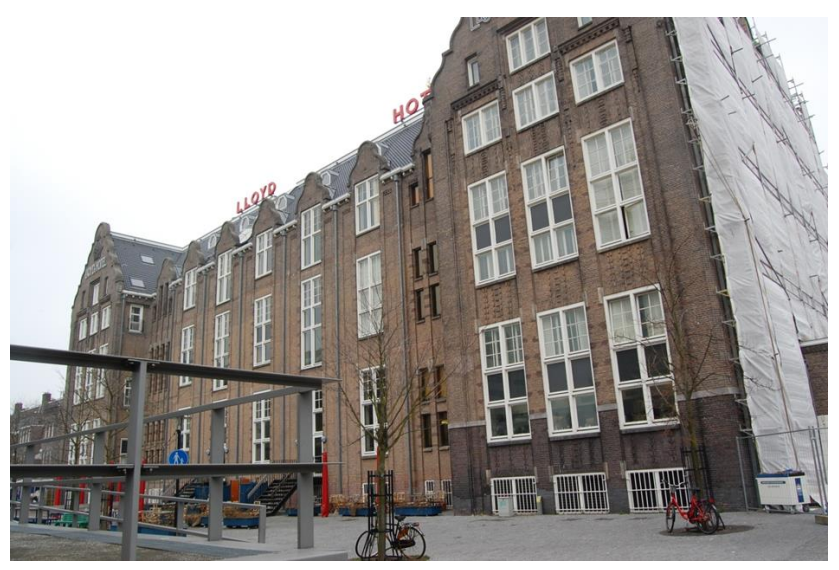

Figure 1. The Lloyd Hotel in its present form.

what we describe as a "quasi-carceral regime". We pay close attention to the changing management of these institutions and their "guests" against the backdrop of different authorities involved and the war developments. We do so by drawing not only from recent insights coming from debates on the so-named "carceral geographies" (see Moran, 2012, 2013; Moran et al., 2012) and refugee studies in geography, and in particular their emphasis on the spatialities of the refugees, but also, crucially, their call for a closer examination of the (micro-)politics and the functioning of "the state" in relation to them (see, among others, Gill, 2010; Darling, 2011; Mountz, 2013). Such an examination of the functioning of the Dutch state furthermore contributes to an existing body of literature on Dutch refugee policies before WWII, especially on the everyday management and lived spaces of the refugees (Berghuis, 1990; Blom and Cahen, 1995; Leenders, 1993; Moore, 1986; Obdeijn and Schrover, 2008), as well as a growing body of work on the Lloyd Hotel in Amsterdam, still lacking an in-depth discussion of this specific period in the building's past (Lubbers, 2004; Ong et al., 2014a, b).

Accordingly, in line with Lemke's reading of Foucault, we refrain from approaching "the state", in this case "the Dutch state", as "a homogeneous, stable actor that exists prior to political action" (Lemke, 2007:10); instead, we suggest taking into consideration the ongoing processes of "state formation", "an emergent and complex resultant of conflicting and contradictory governmental practices" (ibidem; also Lemke, 2011; Martin, 2012; Nyers, 2006). Furthermore, we aim to illustrate how the Foucauldian concepts of "technologies of domination" and "technologies of the self", the first originating from the French philosopher's analysis of prisons and mental hospitals and the second deriving from his study of sexuality (Foucault, 1977, 1993, 1994a, 1994b, 2000, 2007), are both relevant in these quasi-carceral spatial formations. Studies of micro-sites have rarely uncovered the concurrent operations of the two sets of governmental technologies. Indeed, what emerged in the period between November 1938 and Hitler's invasion of the Netherlands on 10 May 1940 (Vis and Moldenhauer, 2000) was a progressive proliferation and intensification of the various state authorities' micro-political interventions via the regimentation of the refugees' mobility. These diversified and somehow incoherent and fragmented interventions, and their related spatialities, had serious implications for the lives of the refugees and the reproduction of their undefined status and vulnerable conditions.

Methodologically, we draw on correspondences between refugee camp commanders based at the Lloyd Hotel and different ministries and committees involved in the governance of the refugees. In addition, we examine the correspondence between the Ministries of Internal Affairs and Justice and the Royal Dutch Marechaussee (the military agency policing the border). Putting these documents in perspective, we revisit key historical literature on the refugee situation in the Netherlands in the prelude to WWII. Texts produced by public figures are reported with actual names, while individual refugee names are pseudonymised. However, before analysing these materials, we provide a brief and inevitably incomplete review of how geographers and others have approached refugee spaces in general, and refugee camps in particular (Minca, 2015a), and have examined the role of the state in managing them. After having discussed the Lloyd Hotel case in some detail, we then conclude by suggesting that revisiting Foucault on these questions may help problematise the role of the state in the spatialisation of custody and care of the refugees' everyday lives and the lived spaces, back then and perhaps today as well.

\section{Governing refugee space}

Hannah Arendt (1958), in her ground-breaking work on totalitarianism, famously describes how, in the prelude to WWII, displaced populations, often subjected to forced mobilisation in their country of origin, formed a particular stateless group that nation states were largely unable to incorporate into their respective juridical systems. Being stateless (and therefore essentially beyond the protection of the law), these groups, once having crossed the border into a neighbouring state, were normally deprived of all fundamental rights - including those of residence, work or citizenship - while at the same time being subjected to constant policing: a form of domination over those "who regardless of any offense committed by individuals found themselves beyond the pale of the law" (Arendt, 1958:288). This was clearly the case in Nazi Germany in 1938, where a politics of denationalisation turned the Jewish citizens into unwanted subjects deprived of any legal status (Agamben, 1998), but it was also the case in non-totalitarian states such as the Netherlands, where Jewish refugees were officially described by government representatives as an "undesirable element" of Dutch society. "If the Nazis put a person in a concentration camp and if he made a successful escape, say, to Holland, the Dutch would put him in an internment camp (...) under the pretext 


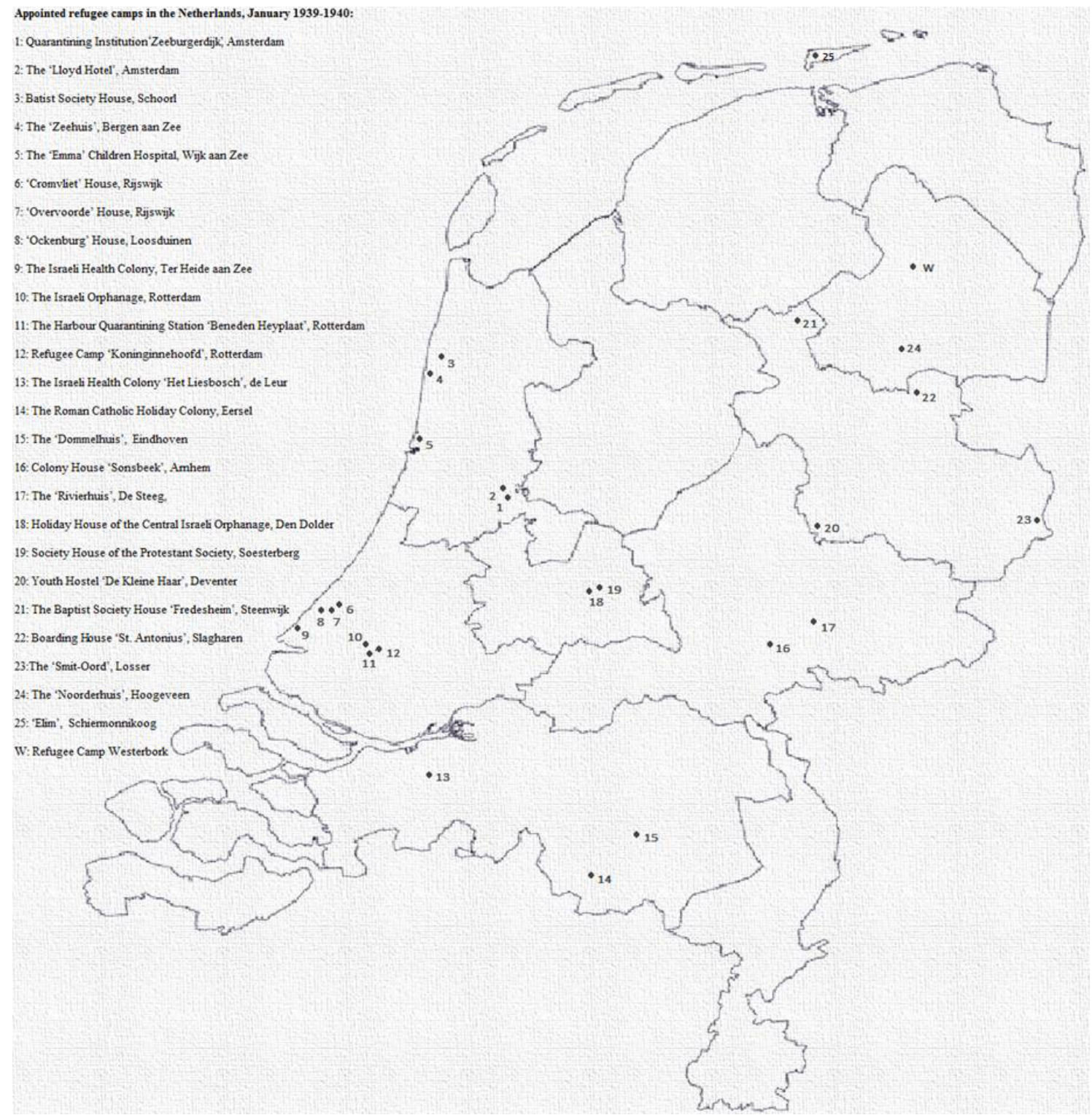

Figure 2. Map of 25 improvised refugee camps.

of national security" (Arendt, 1958:288). Arendt, in particular, reflects on the difference between the consequences of having committed an offense before the law and those of not being recognised as subject to the law. Arguably, all too often both "offenders" and refugees were treated in the framework of somewhat similar arrangements of spatial segregation, to keep them in "custody" away from the wider society via a network of prisons and (refugee) camps marked by quasicarceral regimes of detention.

Two key strands of geographical inquiry that can, broadly speaking, be traced back to these early considerations from Hannah Arendt are important for our present investigation. First, Giorgio Agamben's (1998) reading of Arendt on this issue has recently inspired a bourgeoning literature dealing not only with the "legal" status of refugees in a world of nation states, their territories and their related exclusive principle of citizenship (e.g. Basaran, 2010; Darling, 2009; Gibney, 2009; Malkki, 1992, 1995; Shewly, 2013; see also Isin and Turner, 2002) but also with how refugee camps have been used from WWII onwards (Hyndman, 2000) to materialise such legislative problems into manageable space, as if spatialising the problem were the best possible response in order to govern this juridical (and political) void (Kitagawa, 2011; Levy, 2010; Van Houtum and Boedeltje, 2009). In these studies, (refugee) camps have been conceptualised as spatialised and materialised states of exception (e.g. Darling, 2011; Diken, 2004; Martin, 2012; on camp geographies see, among others, Diken and Laustsen, 2005; Ek, 2006; Giac- 
caria and Minca, 2011a, b; Minca, 2005, 2006, 2007, 2015a; Ramadan, 2013). Second, the term "carceral geography" has been recently coined in order to describe a "new and vibrant field of geographical research into practices of incarceration" (Moran, 2012:306). This field is highly indebted to both the work of Agamben and Foucault and has explored how prisons could be approached as spaces of exception and how acts of domination and tactics of control, containment and surveillance have been spatialised in different ways (Martin and Mitchelson, 2009; Minca, 2015b; Moran, 2012, 2013), including "mobilities as expressions of power" (Moran et al., 2012:446; De Genova and Peutz, 2010).

Research on refugee regimes has also largely tapped into Foucault's "governmental approach" in order to further examine the determination, management and control over these individuals with an unclear and temporary status before the state (e.g. Christie and Sidhu, 2006; Hanafi and Long, 2010; Hardy, 2003; Hyndman, 2000; Martin, 2012; Mountz, 2013; Mountz et al., 2012; Soguk, 1999; Zetter, 1991). The growing literature in refugee studies - difficult to adequately recall in its multiple ramifications in the limited space here available - has therefore focussed on many different governmental aspects of the refugee problem, including how nation states have come to deal with refugees in a globalising world (Agnew, 2009; Bauder, 2014; Gibney, 2009; Lui, 2004; Muller, 2004); how technologies of control, surveillance and subjectification enforce forms of self-regulation of/by refugees inspired by certain ideals endorsed by the state (Lippert, 1999:308); and how management, status and recognition procedures influence the refugees' everyday lives from the perspectives of the refugees themselves (Brun, 2001; De Genova, 2002; Steindl et al., 2008). Although such approaches have examined and problematised the governance of refugee spaces in important ways, Gill (2010) observes that states' policies and institutions often continue to be approached as if they were merely the enactment of specific grand and coherent visions formulated by the state authorities, or even embedded in clearly rational plans and delineated sets of rules and formal bodies. In doing so, many studies on refugees have relatively underplayed the effects of forms of micropolitics produced and enacted by the actual everyday practices related to the management of refugees, together with the implications of such processes on the status, spatial regimentation and mobilities of these subjected individuals. As emphasised by Darling (2011:270), further studies on refugee regimes should be sensitive to "the ways in which governmental rationalities are complex and conflicted configurations of interests, tactics and modes of power without a singular point of authority or calculation" (see also Martin, 2012; Mountz, 2013; Tyler, 2010) and in a constant state of formation (Nyers, 2006).

In Discipline and Punish (1977) Foucault famously shows how government structures and technologies of control, surveillance and subjectification work and how the apparatus of punitive justice has historically evolved with the con- solidation of the modern state, from previous preoccupations of inflicting punishment onto the body towards "making the offender not only desirous, but also capable of living within the law and providing for his own needs" (Foucault, 1977:18; also 1994a, b, 2000). These mutations in dealing with offenders are associated by the French philosopher with particular modes of thinking, themselves a contingent product of power relations between the different institutions involved. In his lectures on "Security, Territory and Population" (19771978), Foucault then moves beyond the apparatus of punitive justice - and its binaries of do's and don'ts - to discuss how the apparatus of security, instead, revolves around the recognising of probable events, the calculation of costs tied to these events and the establishment of a bandwidth of acceptable occurrence that must not be exceeded.

\begin{abstract}
The law prohibits and discipline prescribes, and the essential function of security, without prohibiting or prescribing, but possibly making use of some instruments of prescription and prohibition, is to respond to a reality in such a way that this response cancels out the reality to which it responds - nullifies it, or limits, checks, or regulates it (2007:69).
\end{abstract}

In the apparatuses of security and disciplining, "effects of domination" can be positioned in different institutions and are attributed to the proliferation of "dispositions, manoeuvres, tactics, techniques, functioning's" (Foucault, 1977). Drawing on previous literature on this, Inda (2005:9; see also Lemke, 2007; Miller and Rose, 1990; Rose and Miller, 1992) defines such dispositives as
methods of examination and evaluation; tech- niques of notation, numeration, and calculation; accounting procedures; routines for the timing and spacing of activities in specific locations; presen- tational forms such as tables and graphs; formulas for the organisation of work; standardised tactics for the training and implantation of habits; peda- gogic, therapeutic, and punitive techniques of re- formulation and cure; architectural forms in which interventions take place (i.e. classrooms and pris- ons); and professional vocabularies.

Foucault's later work on governmentality partly problematises his earlier emphasis on disciplining and docile bodies, and moves beyond technologies of domination to provide an additional reading of "power" as a form of guidance, "shaping the field of possible action of subjects" (Lemke, 2010:52). Government, according to Foucault, comprises technologies of domination through relationships that are hierarchical, fixed, prescribing, controlling and judging. Conversely, however, government also comprises guidance, allowing for spaces and processes through which "the self is constructed or modified by himself" (Foucault, 1993:203204). 
The contact point, where the individuals are driven by others is tied to the way they conduct themselves, is what we can call, I think, government. Governing people, in the broad meaning of the word, governing people is not a way to force people to do what the governor wants; it is always a versatile equilibrium, with complementarity and conflicts between techniques which assure coercion and processes through which the self is constructed or modified by himself (ibidem).

Following Foucault we might therefore question how the Dutch state governed the refugee problem and examine how a plurality of institutions were entangled in a micro-physics of power and deployed specific rationalities, programmes, tools and tactics in managing these stateless individuals and their lived spaces in the prelude to WWII, both via technologies of domination (judging, prescribing, controlling) and through technologies of the self (guidance, education, reflection).

\section{Rationalities and technologies of control: temporary residence permits, personality cards and "camps"}

We would like to start our analysis by recalling the general political climate that contributed to framing in a specific way the refugee problem in the Netherlands before WWII. This will hopefully help in examining the rationalities of and the power relations between the different authorities involved in dealing with the refugees in those days, and how these were rationally implemented and affected the refugees' lived spaces at the Lloyd Hotel.

Hitler's political takeover of Germany in 1933, and the consequent measures implemented against Jewish citizens, had led many of them to leave the country and look for a new home elsewhere, including the neighbouring Netherlands, with over 24000 German Jews entering the country between 1933 and 1938 (Lubbers, 2004:73). However, the recession in the 1930s and the consequent unemployment rates had strongly influenced the government policies towards foreigners. In 1934, a law was passed not to allow foreigners to work in particular sectors. In 1936, this legislation was extended to almost all forms of waged labour (Obdeijn and Schrover, 2008). In 1937, another law banned foreigners from settingup their own businesses, such as confection industries, trade agencies and commission trades (Leenders, 1993). In addition, from 1934 onwards German Jews in particular were only admitted to the Netherlands on a temporary basis and if they could prove they were financially self-supporting. These interventions were driven by the general idea that, because of the lack of work opportunities and of the temporary status of their permits, Jewish and political refugees from Germany would be encouraged to move on to other destinations (Obdeijn and Schrover, 2008). The then minister of justice, Josef van Schaik, tellingly described the refugees as "an undesirable element in Dutch society" (cited in Leenders, 1993:246).

In 1938, after Hitler's Anschluss of Austria, the Dutch authorities (the Ministry of Justice in particular) made policies concerning German-Jewish refugees even more stringent. It was no longer enough to be self-supporting. Jewish and political refugees were averted at the border and, if identified in the country, deported back to Germany. Only women, children and those who could prove to be in immediate danger had the chance to be admitted. This tightening of policies, however, was suspended after the infamous Kristallnacht in November 1938, since this tragic event suddenly changed how refugees from Germany were perceived in the Netherlands. In the words of President Hendrikus Colijn (1938, cited in Berghuis, 1990:25): “As we speak, the German-Jewish citizens that are under immediate pressure need to cross our $330 \mathrm{~km}$ long border... Research into requests for visiting permission needs to be hastened... There are an estimated 600000 Jews in Germany... Do we need to accept 10000 , do we need to accept 5000?" Under pressure from public opinion and opposition parties, the Dutch Parliament decided to admit 2000 refugees, a number raised to 9000 in the following months (Leenders, 1994). This relaxation of the policies however was only momentary. On 17 December 1938, the new minister of justice, Carel Goseling, ordered that all refugees entering the Netherlands from that moment on would be immediately deported to the German border - an important exception, again, being women and children who crossed the border individually (ibidem).

The government's rationalities on how to deal with the refugee problem proved indeed to be rather fragmented and inconsistent during the whole of the 1930s. The Ministries of Internal Affairs and Justice, for example, aimed for stricter measures against the refugees, mainly preoccupied with their impact on domestic politics, while the Ministry of Foreign Affairs was more lenient, taking into account the broader context of international relations (Moore, 1986). Consequently, in the period 1934-1938, the related policies and procedures tended to be vague and contradictory, often being modified and differently interpreted and implemented by the authorities "on the ground" (e.g. border control and police forces). The different ministries also applied different monitoring systems.

In October 1938, for example, an inspector of the Royal Dutch Marechaussee requested 11 more employees to the Ministry of Justice to deal with the administrative burden related to the registration of a rapidly increasing inflow of refugees (Dutch National Archive, 1938). Minister Goseling however saw no need for such an intervention and called for more efficient administration procedures to be implemented.

Not every businessman or tourist has to be included in this cartotheek (administrative system of the Royal Dutch Marechaussee based on a collection 
of cards with data); from a policing point of view there is no need for that either (ibidem).

Although not every foreigner needed to be registered, according to the same ministry, it was instead essential to track "how many Jewish refugees are making use of Dutch hospitality" (ibidem). To get an idea of the number of Jewish refugees present in the Netherlands, the temporary residence permits (see Fig. 3) distributed had to be carefully counted. Refugees, in fact, needed to register and declare the purpose of their visit (including seeking asylum) and their place of residence at the local police offices immediately after entering the Netherlands. Copies of these permits were then sent to the Marechaussee "labelled with a capital J", to keep them distinct from other documents (ibidem). All refugees failing to report to the local authorities within 30 days, or crossing the border without a visa, were considered illegal and faced eviction under the jurisdiction of the Ministry of Justice. Those with the permit were considered legal and subject to the Ministry of Internal Affairs.

To collect further information on these legal refugees, the Ministry of Internal Affairs had created a centralised registration system implemented at three administrative levels: nationally, in the "Population Register"; locally, in the "Municipality Register"; and, when the refugees were housed in camps, in the respective camps' records. The key tool of this administrative machine however was not the permit but the "personality card". This card was essentially a collection of information regarding each refugee's "psychological and physical state and his social and economic relations in the country" (Dutch National Archive, 1939). Data needed to be collected by refugee camp personnel from "passports and birth-certificates as well as through interviews and observations" (ibidem).

The collected information has to be sent to the centrally administered Population Register where it is officialised and communicated to the Municipality where the camp is located... Once approved by the Municipality, the personality card is filed by the administrative levels involved... Any changes on the refugees' whereabouts need to be sent immediately by the camp personnel to the inspector of the Population Register (ibidem).

In practice, this monitoring system soon turned into a biopolitical machinery in which any movement of the refugees was to be approved and recorded by a total of five different authorities: the camp commander, the local head of police, the Ministry of Internal Affairs and the Jewish committees representing the refugees before the state authorities. Aiming to control an acceptable number of refugees and to monitor their mobility required, according to Foucault, "a whole disciplinary series that proliferates under mechanisms of security" (2007:22), involving different institutions and applying different rationalities and technologies to recognise "certain" refugees allowed to enter the Netherlands, while, at the same time, aiming to control and fix these legal refugees "in space" via a set of disciplinary and security dispositives.

\section{The Lloyd refugee camp: control, care and technologies of the self}

Before November 1938, many legal refugees were housed with Dutch relatives or benefactors. The Jewish Refugee Committee played an important part in facilitating this. As the refugee numbers dramatically increased after the Kristallnacht, and, as Dutch refugee policies tightened, many of those who succeeded in crossing the German-Dutch border ended up in improvised refugee camps. Twenty-five such camps were established after 9 November 1938 (Lubbers, 2004). Their populations varied widely, ranging from families to individuals and from young to old. Even though "legal" and "illegal" refugees had different status and were subject to different ministries, they were occasionally housed in the same encampments (Dutch National Archive, 1939).

The Lloyd Hotel operated as an improvised camp starting from 16 February 1939 initially admitting 186 refugees (ibidem). The camp was first managed by Commander van Outeren and, after August 1939, by Commander Pattist and supported by two porters, a nurse and several civil workers and volunteers. Commander van Outeren created a system of self-maintenance. Young and skilled men were involved in construction work, while younger women helped in cleaning and laundry work. At one time, there were four doctors amongst the refugees who supported the Dutch nurse in her caring of the ill. Some skilled refugees provided shoemaking workshops or taught the children (ibidem). The older children studied in Amsterdam; younger women attended nursery, housekeeping and sewing schools; and men were taught leather work, music and even chemistry (ibidem). English courses were open to all. Most training was planned in ways that did not interfere with the daily chores. For instance, Commander Pattist wrote to the Jewish Refugee Committee, on 23 November 1939, not to request the camp's young women to come and receive laundry work during morning hours as "this would seriously disrupt their duties in the maintenance of camp" (ibidem). In doing so, the camp commander's provision of enrichment activities may in some way be compared to the indoctrination of western liberal values in education programmes of present-day detention (Conlon and Gill, 2013). Like in the case of asylum seekers in Ireland and the UK illustrated by Conlon and Gill's (2013) study, enrichments programmes were likely to have been subscribed to by refugees at the Lloyd Hotel in the hope of eventual inclusion into destination societies.

As a result of the dedicated efforts taken by the commanders to provide the refugees with relatively enriching lives by facilitating various training activities, many of them and their 
Dutch relatives were grateful. In a letter to the commander, Mr. Gimbel wrote:

I feel obliged to - now my mother Mrs. Gimbel no longer resides at your camp, and as you know she now stays at my house - thank you sincerely for the good care that you have given her while staying there (Dutch National Archive, 1939).

Although camp commanders tried to "care" for refugees' quality of life, they strictly ensured that all activities were in line with the overall quasi-carceral management of the camp (Lubbers, 2004). The refugees' movements were carefully monitored: whether they went to apply for visas, visit the Jewish Refugee Committee or attend school, all refugees needed to check out and check in at the porters each time they left and entered the building. Irregularities were reported to the commander. The porters also ensured that "corridors, sitting room and canteen are opened and closed at the proper times" and that "nothing out of the ordinary" occurred. At 11:15 p.m., they conducted final inspections, turning out the lights and locking the doors, ensuring that "everybody is present in their assigned sleeping halls and that everything is quiet" (ibidem).

This is illustrated by the following letter of Commander van Outeren to the American Embassy after the late return of the Hinzelmanns:

Mr. and Mrs. Hinzelmann have visited your embassy yesterday to request for a visa. I would very much like to know at what time they left your embassy because they returned to Lloyd Hotel at 10 p.m. As it is necessary for me to retain full control over the refugees, and leisure trips needs to be fully discouraged, you are required to tell me what happened yesterday. Mr Hinzelmann declared that you refused to sign his yellow leave card. Is this true? (Dutch National Archive, 1939; emphasis added).

Initially, refugees obtained exit permission from the Ministry of Internal Affairs directly or the Jewish Refugee Committee indirectly. However, this entailed a huge administrative task for the ministry, which found it very daunting to assess whether these requests were genuine or not (ibidem). When refugees realised health reasons worked in securing exit permission, many became strategically "sick". In the words of Commander Pattist:

Despite the numerous health related requests for leave and release, the health conditions at the camp are good. Many of these are the result of the perception that the refugees have that only requests for leave on medical grounds are granted (ibidem).

Consequently, the Ministry of Internal Affairs decided that only the camp commander was entitled to submit such requests, and to advise on whether they should be granted, although medical leave had to be endorsed by a physician. Furthermore, visits to the Jewish Refugee Committee could, from that moment onwards, only be permitted with a direct written request from the committee to the commander. From the commander's standpoint, this restrictive procedure was implemented because many such visits were attempts to dodge camp work or for leisure in the city (ibidem). Through these different measures, the camp commander became the linchpin in the network of authorities authorising the refugees' mobility.

From correspondences between Commander Pattist, the Jewish Refugee Committee and the Ministry of Internal Affairs, it emerges that the behaviour and even the mentality of his refugee subjects were also monitored. These observations were indeed influential in endorsing or rejecting requests to leave the camp. Arguably, in that quasi-carceral contingency, being considered a respectable gentleman, a skilled and hard worker, or a sincere individual, at least in the eyes of Commander Pattist, became key criteria for many to maintain a degree of freedom and mobility.

Following your request of information regarding Dr. Köppler I can confirm (...whereabouts). I have come to know him as a very modest, docile person and have heard from trustworthy acquaintances that he is praised both as a person and as a musician. He appears to me in all respects as a gentleman who behaves accordingly and who can be placed in a Dutch family without any problems (Dutch National Archive, 1939; emphasis added).

While being a well-known "gentleman" aided Dr. Köppler's cause in getting a placement in his relative's home outside the confines of the camp, the contrary was true for refugee Schreiber, identified and categorised as a "tremendous poseur" and whose parents' request for him to be moved out of the camp for sleep-related reasons was questioned.

However, the boy is repeatedly caught reading novels secretly, and he has once been punished with skipping classes. According to the doctor, the boy is a tremendous poseur who faked an angina pectoris after witnessing the effects from another patient (...). The motive of his parents that the boy doesn't get enough sleep at the camp is, to me, not valid (ibidem).

To keep track of the status and whereabouts of refugees, and advise on and report about their individual personality, the commanders kept different lists, some classifying the refugee population into specific broad categories: male, female, children, Jewish, Protestant, Catholics and legal/illegal (see Fig. 4). Others reported on the characteristics and skills that these individuals possessed, such as "good organiser, leader of chores in the camp", "very good with children", "very ill", etc. (ibidem). 


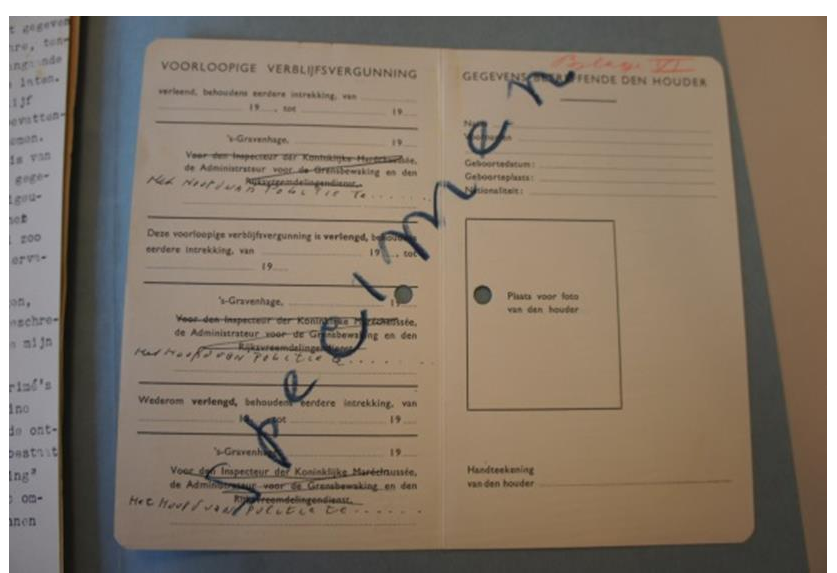

Figure 3. A temporary residence permit.

Through focussing closely on the management of the camp, the commander and the refugees, a clear example of Foucault's "government" and its contact points between technologies of domination and technologies of the self emerges. The camp can indeed be identified as a spatial distribution of hierarchies, gatekeeping, control and classification; it can also be identified as a site where individuals were guided, educated, trained and cared for. In various ways, these technologies were not separate; instead, technologies of self and domination merged in different modes of governance, custody and surveillance, at different times and between different (power) relations.

\section{Custody and surveillance re-spatialised: towards one single refugee (concentration) camp}

In the prelude to WWII, the messiness of the different administrative systems, the 25 different refugee camp locations, the constant flow of refugees between these camps and, most importantly, the fact that the majority of the refugees were not able to get a visa for another country presented the Dutch authorities with a new and increasingly urgent problem (Obdeijn and Schrover, 2008). It soon became clear that most of the refugees - also in light of developments in international politics - were in the Netherlands to stay. Furthermore, the unclear division in responsibilities amongst the (lowerranked) authorities and the "disciplinary series that proliferate[d] under [the implemented] mechanisms of security" (Foucault, 2007:22) resulted in the impossibility of actually monitoring the management of these 25 temporary refugee camps. As a result of this realisation, the Ministry of Internal Affairs decided to build one single centralised camp for the entire country. The refugees were accordingly either placed with Dutch relatives (see Fig. 5) (with the Jewish Refugee Committee being financially responsible for them) or transported to this new centralised institution, also financed by the Jewish Refugee Committee (Obdeijn and Schrover, 2008).

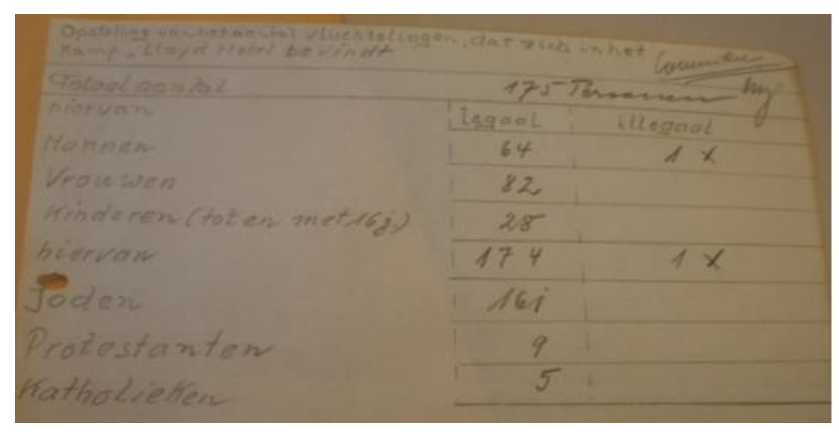

Figure 4. Lists to categorise and track the refugee subjects.

The construction of the new camp started in November 1939, using the refugees themselves as labour force, in an isolated site near Westerbork in Drenthe, a long way from Amsterdam (Memorial Centre Camp Westerbork, 2013).

However, the Nazis invaded the Netherlands on 10 May 1940, taking full control over the country in 5 days (Vis and Moldenhauer, 2000). Plans had been made by the Dutch government to evacuate the refugees housed in Camp Westerbork in the event of an invasion. In the maelstrom of that tragic moment, however, the evacuation was never executed. However, the secretary general of the Ministry of Justice, Jan Coenraad Tenkink, did everything he could to ensure that all refugees who had escaped during the invasion could be identified and returned to the camp (Memorial Centre Camp Westerbork, 2013). Camp Westerbork was transformed, under Nazi rule, into an important Durchgangslager (transit camp) for the deportation of over 107000 Jewish people from the Netherlands to the infamous concentration and extermination camps in Eastern Europe and Germany (ibidem). Not only did the Nazis find in the Netherlands a wellmanaged and centralised camp where many of the GermanJewish refugees were concentrated, they also confiscated the large amount of data collected by the different authorities involved in the management of the refugee problem $(\mathrm{Ob}-$ deijn and Schrover, 2008). In particular, the abovementioned "Population Register" kept by the Ministry of Internal Affairs, containing key information concerning the address and the relations between German-Jewish refugees and DutchJewish citizens, became an important tool for the Nazi's identification and persecution of both groups.

\section{Conclusions}

Reflecting on the material discussed in this paper, we would like to conclude that the sudden inflow of Jewish refugees into the Netherlands presented the Dutch authorities with an unexpected emergency situation associated with a political and moral dilemma. On the one hand, partly due to public pressure, they wanted to rescue these people from the immediate threat posed by the Nazi regime. On the other, they had no intention of incorporating them into Dutch society. The 


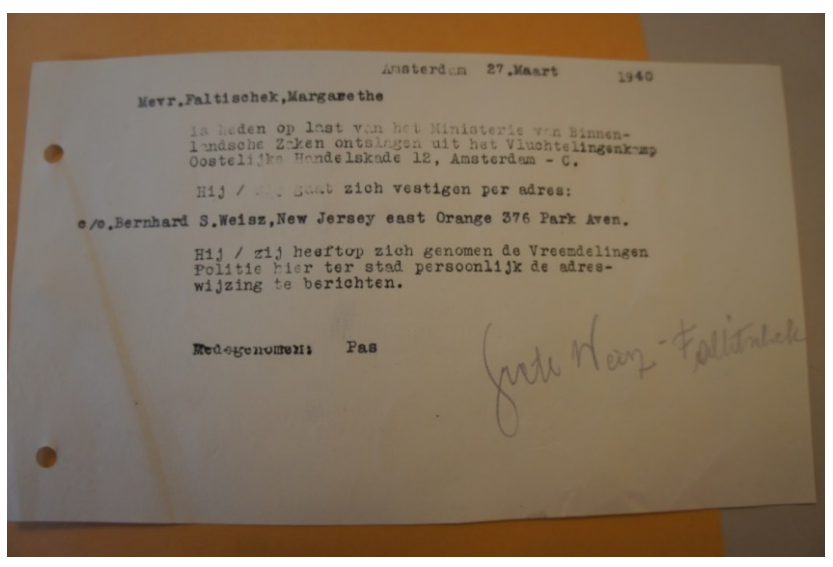

Figure 5. Permission to leave the camp.

result of this ambivalent attitude was the presence on Dutch territory of a group of people with an unclear status. In order to deal with this problem, the refugees were then provided with a temporary residence permit under the assumption that they would eventually be moving on to other countries. To support this transition, they were also "allowed" a calculated and acceptable mobility to visit embassies to apply for visas, but at the same time their contact with Dutch society was severely "regulated" and "restricted", thereby giving them no reason to stay. Here we can see apparatuses of both security and discipline at work, enrolled in the macro-politics of the Dutch government's temporary approach to the refugee problem.

To contain its implications for the refugees, as well as for Dutch society at large, this temporary and uncertain situation was initially spatialised by the Dutch authorities via the establishment of 25 temporary refugee camps. Despite their quasi-carceral regime, these camps were relatively embedded in the spatialities of the several Dutch cities. This was particularly the case with the Lloyd Hotel, as illustrated in this article. Overall, the regime implemented by this archipelago of camps reflected the ambiguity and the relative confusion of the policy strategies (as well as the political imperatives) implemented by the Dutch bodies in charge of managing these refugees. Again, the refugees were subjected to a certain form of custodian care. Those staying at the Lloyd Hotel, for example, could partake in courses both in and outside the camp, and there were efforts taken to house them with Dutch relatives. At the same time, the refugees were subjected to constant policing and authorised to leave the camp perimeter only for specific reasons, thus limiting their exposure to Dutch society. Precisely due to the combination of these micro-politics and acts of control, containment and care, we argue that these camps, and the Lloyd Hotel in particular, were characteristic of a quasi-carceral regime.

There were many different authorities involved in the management of these camps, resulting in a certain administrative messiness, since they created different monitoring sys- tems reflecting different problems at stake: classifying the refugees as legal or illegal, reporting their whereabouts and monitoring their behaviour. Such control and regulation of refugee subjects entailed the proliferation of governmental technologies: the personality cards, the paperwork to grant permission to exit the camp or stay with relatives, the mobility between camps based on skills and crafts. Being qualified, within some of these classificatory systems, as "gentleman" or "skilled and relevant craftsman" helped promote forms of discipline within the refugee communities. Indeed, as more power was given to the commander in deciding (rather arbitrarily) over permissions to leave the camp, it became important to be classified as a "good refugee" in order to obtain such "privileges". These observations, we believe, fit well within recent work trying to problematise the sharp boundaries between states and their action "upon" refugees and arguing that in the sovereign creation of bare life, according to Agamben, both technologies of control and care and technologies of the self should be taken into account (Martin, 2012; Shewly, 2013).

Following the realisation that most countries had stopped admitting Jewish refugees, the Ministry of Internal Affairs gave up on the idea that they were simply passing through. The temporary status of these refugees had thus become an even bigger political and ethical problem in need of a more permanent solution. The Ministry did so by "re-spatialising" again the refugees, as if following the principles of spatial concentration and segregation to their full potential the problem could somehow be contained and made more manageable. As a consequence, those who could not afford to stay with Dutch relatives were brought to one centralised and isolated camp. In this new segregated condition, they had no perspectives to gain Dutch citizenship or real chances to move on to other countries. Instead, although unintentionally, they had somehow been prepared by the authorities to be deported en mass to other concentration camps, which did indeed happen after the Nazis took over the country.

By illustrating the successive stages in the production of the refugees' spatialities, and by focusing on the Lloyd Hotel case in particular, we have therefore tried to disclose how, in these regimes of uncertainty and (spatial) exclusion, power relations and technologies of domination and the self played out at different levels, from the ministries to the camp commanders to the refugees themselves, and how both macroand micro-politics had consequences for their actual mobility and related living conditions, with enormous implications for subjected individuals. Furthermore, the establishment of Camp Westerbork illustrates how the Ministry of Internal Affairs overruled other authorities, such as the camp commanders, in order to implement their own calculative rationality and enforce them upon the refugees by concentrating most of them into a single isolated secluded institution. What this implied was the actual deportation of refugee population to this centralised camp in order to "govern them differently than provided for by the usual laws of the state" 
(Basaran, 2010:88). A population categorised and classified by, and subject to, the Dutch authorities but at the same time considered as beyond their responsibility (for a critical examination on this, Basaran, 2010) - "abandoned", as it was, into a genuine state and space of exception that the Nazis would be keen to incorporate into their own strategies concerning the Jewish refugee problem (see Agamben, 1998, and, among many others, Giaccaria and Minca, 2011a; Minca, 2005, 2006, 2007). Indeed, in an extreme act of selfdisciplining, the camp was built by the refugees themselves and managed at the expense of the refugee committees.

With this brief reconstruction of the production of the refugees' spatial regimes, from their arrival in the Netherlands to their final spatialisation in Camp Westerbork and the transformation of that camp into a Nazi transit camp, we have aimed to illustrate how the refugees' status and lives were subject to and created by different authorities in shifting power relations. Like the authorities themselves, these lives - and their value - were therefore in a constant state of formation (see also De Genova and Peutz, 2010; Nyers, 2006), for better or for worse. The endless attempts to spatially marginalise these stateless people in the hope that they would move further, precisely because of their untenable conditions, reveal how quasi-carceral regimes are all too often the breeding grounds for violence and further imprisonment, like many contemporary cases seem to suggest as well (Martin, 2012). As described in this article, concentration and segregation - being conditions that facilitate identification, classification and the implementation of biopolitical calculative dispositives - certainly applied to the quasi-carceral regimes in the early stages of the Jewish refugee "problem" in the Netherlands in the prelude to WWII. This was to help prepare the ground for the following, incrementally more carceral regimes, ending in deportation and, for many, death.

Edited by: J. Turner

Reviewed by: three anonymous referees

\section{References}

Agamben, G.: Homo Sacer, Chicago University Press, Chicago, 1998.

Agnew, J.: Globalization and Sovereignty, Rowman and Littlefield, Lanham, 2009.

Arendt, H.: The Origins of Totalitarianism, Meridian, New York, 1958.

Basaran, T.: Security, Law and Borders, Routledge, London, 2010.

Bauder, H.: Domicile citizenship, human mobility and territoriality, Prog. Hum. Geog., 38, 91-106, 2014.

Berghuis, C. K.: Joodse vluchtelingen in Nederland, 1938-1940, Kok, Utrecht, 1990.

Blom, J. C. and Cahen, J. J.: Joodse Nederlanders, Nederlandse joden en joden in Nederland 1870-1940, in: Geschiedenis v.d. joden in Nederland, edited by: Blom, J. C., Balans, Amsterdam, 1995.
Brun, C.: Reterritorializing the Relationship between People and Place in Refugee Studies, Geogr. Ann. B, 83, 15-25, 2001.

Christie, P. and Sidhu, R.: Governmentality and "fearless speech": framing the education of asylum seeker and refugee children in Australia, Oxford Rev. Educ., 32, 449-465, 2006.

Conlon, D. and Gill, N.: Gagging orders: asylum seekers and the paradoxes of freedom and protest in liberal society, Citizenship Studies, 17, 241-259, 2013.

Darling, J.: Becoming bare life: asylum, hospitality, and the politics of encampment, Environ. Plann. D, 27, 183-189, 2009.

Darling, J.: Domopolitics, governmentality and the regulation of asylum accommodation, Polit. Geogr., 30, 263-271, 2011.

De Genova, N. P.: Migrant "Illegality" and Deportability in Everyday Life, Annu. Rev. Anthropol., 31, 419-447, 2002.

De Genova, N. P. and Peutz, N. (Eds.): The Deportation Regime, Duke University Press, Durham, 2010.

Diken, B.: From refugee camps to gated communities, Citizenship Studies, 8, 83-106, 2004.

Diken, B. and Laustsen, C. B.: The Culture of Exception, Routledge, London, 2005.

Dutch National Archive: inventory numbers 2.09.45 and 2.04.58, 1938-1940.

Ek, R.: Giorgio Agamben and the spatialities of the camp, Geogr. Ann. B, 88, 363-386, 2006.

Foucault, M.: Discipline and Punish: the Birth of the Prison, Penguin, London, 1977.

Foucault, M.: About the beginning of the hermeneutics of the self, Polit. Theory, 21, 198-227, 1993.

Foucault, M.: Sexuality and solitude, in: Michel Foucault: ethics, subjectivity and truth, edited by: Rabinow, P., The New Press, New York, 1994a.

Foucault, M.: Governmentality, in: Michel Foucault: power, edited by: Rabinow, P., The New Press, New York, 1994b.

Foucault, M.: The subject and power, essential works of Michel Foucault Vol.III, The New Press, New York, 2000.

Foucault, M.: Security, Territory, Population, Palgrave Macmillan, Basingstoke, 2007.

Giaccaria, P. and Minca, C.: Topographies/topologies of the camp: Auschwitz as a spatial threshold, Polit. Geogr., 30, 3-12, 2011 a.

Giaccaria, P. and Minca, C.: Nazi biopolitics and the dark geographies of the selva, Journal of Genocide Research, 13, 67-84, $2011 b$.

Gibney, M.: Statelessness and the Right to Citizenship, Forced Migration Review, 32, 50-51, 2009.

Gill, N.: New state-theoretic approaches to asylum and refugee geographies, Prog. Hum. Geog., 34, 626-645, 2010.

Hanafi, S. and Long, T.: Governance, Governmentalities, and the State of Exception in the Palestinian Refugee Camps of Lebanon, J. Refug. Stud., 23, 134-159, 2010.

Hardy, C.: Refugee Determination Power and Resistance in Systems of Foucauldian Power, Admin. Soc., 35, 462-488, 2003.

Hyndman, J.: Managing Displacement, Minneapolis, University of Minnesota Press, 2000.

Inda, J. X. (Ed.): Anthropologies of Modernity, Blackwell, Oxford, 2005.

Isin, E. F. and Turner, B. S. (Eds.): Handbook of Citizenship Studies, SAGE, London, 2002. 
Kitagawa, S.: Geographies of Migration Across and Beyond Europe, in: Europe in the World, edited by: Bialasiewicz, L., Ashgate, London, 2011.

Leenders, M.: Ongenode gasten: van traditioneel asielrecht naar immigratiebeleid, 1815-1938, Uitgeverij Verloren, Hilversum, 1993.

Lemke, T.: An indigestible meal? Foucault, governmentality and state theory, Distinktion, 8, 43-64, 2007.

Lemke, T.: Foucault, Governmentality, and Critique, Rethinking Marxism, 14, 49-64, 2010.

Lemke, T.: Bio-Politics: An Advanced Introduction, New York University Press, New York, 2011.

Levy, C.: Refugees, Europe, camps/state of exception, Refugee Survey Quarterly, 29, 92-119, 2010.

Lippert, R.: Governing refugees, Alternatives, 24, 295-328, 1999.

Lubbers, A.: Lloyd Hotel, Bas Lubberhuizen, Amsterdam, 2004.

Lui, R.: The international government of refugees, in: Global Governmentality, edited by: Larner, W. and Walter, W., Routledge, London, 2004.

Malkki, L.: National geographic: the rooting of peoples and the territorialization of national identity among scholars and refugees, Cult. Anthropol., 7, 24-44, 1992.

Malkki, L.: Refugees and exile: From "refugee studies" to the national order of things, Annu. Rev. Anthropol., 24, 495-523, 1995.

Martin, D.: The "Where" of Sovereign Power and Exception, PhD thesis, Durham University, 2012.

Martin, L. and Mitchelson, M.: Geographies of detention and imprisonment, Geography Compass, 3, 459-477, 2009.

Memorial Centre Camp Westerbork: http://www.kampwesterbork. nl/, last access: 25 March 2014.

Miller, P. and Rose, N.: Governing economic life, Econ. Soc., 19, 1-31, 1990.

Minca, C.: The return of the camp, Prog. Hum. Geog., 29, 405-412, 2005.

Minca, C.: Giorgio Agamben and the new biopolitical nomos, Geogr. Ann. B, 88, 387-403, 2006.

Minca, C.: Agamben's geographies of modernity, Polit. Geogr., 26, 78-97, 2007.

Minca, C.: Geographies of the Camp, Polit. Geogr., forthcoming, 2015a.

Minca, C.: The biopolitical Imperative, in: A Companion to Political Geography, edited by: Sharp, J., Agnew, J., Mamadouh, V., and Secor, A., Blackwell, Oxford, forthcoming, 2015b.

Moore, B.: Refugees from Nazi Germany in the Netherlands 19331940, Nijhoff, Dordrecht, 1986.

Moran, D.: "Doing Time" in Carceral Space, Geogr. Ann. B, 94, 305-316, 2012.
Moran, D.: Carceral geography and the spatialities of prison visiting, Environ. Plann. D, 31, 174-190, 2013.

Moran, D., Piacentini, L., and Pallot J.: Disciplined mobility and carceral geography, T. I. Brit. Geogr., 37, 446-460, 2012.

Mountz, A.: Political geography I: Reconfiguring geographies of sovereignty, Prog. Hum. Geog., 37, 829-841, 2013.

Mountz, A, Coddington, K., Catania, R. T., and Loyd, J. M.: Conceptualizing detention: mobility, containment, bordering, and exclusion, Prog. Hum. Geog., 37, 522-541, 2012.

Muller, B.: Globalization, security, paradox: towards a refugee biopolitics, Refuge, 22, 49-57, 2004.

Nyers, P.: Rethinking Refugees: Beyond States of Emergency, Routledge, London, 2006.

Obdeijn, H. and Schrover, M.: Komen en Gaan. Immigratie en emigratie in Nederland vanaf 1550, Bert Bakker, Amsterdam, 2008.

Ong, C. E., Minca, C., and Felder, M.: Disciplined Mobility and the Emotional Subject in Royal Dutch Lloyd's Early Twentieth Century Passenger Shipping Network, Antipode, 46, 1323-1345, 2014a.

Ong, C. E., Minca, C., and Felder, M.: The Historic Hotel as "QuasiFreedom Machine": Negotiating Utopian Visions and Dark Histories at Amsterdam's Lloyd Hotel and "Cultural Embassy", Journal of Heritage Tourism, forthcoming, 2014b.

Ramadan, A.: Spatialising the refugee camp, T. I. Brit. Geogr., 38, 65-77, 2013.

Rose, N. and Miller, P.: Political Power beyond the State, Brit. J. Sociol., 43, 173-205, 1992.

Sherman, A. J.: Island refuge: Britain and refugees from the Third Reich 1933-1939, University of California Press, Los Angeles, 1973.

Shewly, H. J.: Abandoned spaces and bare life in the enclaves of the India-Bangladesh border, Polit. Geogr., 32, 23-31, 2013.

Soguk, N.: States and strangers: Refugees and displacements of statecraft, University of Minnesota Press, Mineapolis, 1999.

Steindl, C., Winding, K., and Runge, U.: Occupation and participation in everyday life, Journal of Occupational Science, 15, 36-42, 2008.

Tyler, I.: Designed to fail: a biopolitics of British citizenship, Citizenship Studies, 14, 61-74, 2010.

Van Houtum, H. and Boedeltje, F.: Europe's Shame: Death at the Borders of the EU, Antipode, 41, 226-230, 2009.

Vis, J. C. P. M. and Moldenhauer, G. (Eds.): Nederland en Duitsland, Uitgeverij Van Gorcum, Assen, 2000.

Zetter, R.: Labelling Refugees, J. Refug. Stud., 4, 39-62, 1991. 